Reprod. Nutr. Dévelop., 1983, 23 (6), $1011-1017$.

\title{
Effects of triiodothyronine and of some gonadotropic and steroid hormones on the maturation of carp (Cyprinus carpio L.) oocytes in vitro
}

\author{
P. EPLER, K. BIENIARZ
}

Academy of Agriculture, Department of /chthyobiology and Fisheries ul I. Ambrosowa 6, Krakow-Mydlniki, Poland.

Summary. The effects of triiodothyronine $\left(T_{3}\right)$ and of gonadotropic and steroid hormones on carp oocyte maturation in vitro were investigated using ovarian fragments from 5 females that had completed vitellogenesis.

The percentages of mature oocytes were consistently greater in the subgroups incubated with $T_{3}+$ steroid hormone, or with $T_{3}+$ gonadotropic hormone, than in the subgroups incubated with the same steroid or preparation of gonadotropic hormone without $T_{3}$. Differences between the first and second groups proved to be statistically significant $(P<0.01)$. The results suggest that $T_{3}$ influenced the maturational response of carp oocytes to some gonadotropic and steroid hormones.

\section{Introduction.}

Many data show that thyroid hormone plays a role in fish reproduction, although its mechanism is not clear (Fontaine, 1976). Very intense activity of the thyroid gland was observed histologically in male salmon species during the spawning period (Barannikova, 1978). In the females of this species, high gonadotroph activity was accompanied by simultaneous and very intense thyrotroph activity (Barannikova, 1978). Intramuscular injections of testosterone propionate in immature trout cause both an acceleration of thyrozine deiodization and an increase in the triiodothyronine $\left(\mathrm{T}_{3}\right)$ level (Hunt and Eoles, 1976).

Blockade of thyroid gland activity by goitrogenesis or destruction of the gland by radioiodine inhibits gonadal development in some teleost fish species (Fontaine, 1976). An investigation by Dettlaff and Davydova (1979) has shown that $T_{3}$ restores gonadotropic sensitivity of the follicular cells in sturgeons kept at too low a temperature or in unsuitable conditions. The participation of thyroid hormones in the gonadal development of goldfish was described in a review by 
Lam et al. (1978) who found that these hormones act in synergy with gonadotropin on vitellogenesis and on the maintenance of the oocytes after completion of vitellogenesis. Sage and Bromage (1970) and Sage and Berin (1971) have shown that the gonadotropic cells at the pituitary level in Poecilia reticulata are inhibited by both androgens and estrogens in vitro but that in vivo estrogens stimulate the TSH cells. Injections of $17 \beta$-estradiol make the thyrotrophs of the European eel more active (Olivereau, 1979). The aim of the present work was to determine if the addition of $T_{3}$ to the incubation medium would influence the maturational response of carp oocytes to gonadotropin or selected steroid hormones (Epler, 1981a, b, c).

\section{Material and methods.}

Investigations were carried out in April using ovarian fragments from 5 adult female carp from commercial carp ponds and weighing 4.5 to $5.0 \mathrm{~kg}$. Twenty-four hours before taking these ovarian samples, the females were injected with carp hypophysial homogenate (chh) at a dose of $0.5 \mathrm{mg} / \mathrm{kg}$ body weight. The oocytes were incubated for $72 \mathrm{~h}$ in vials with $2 \mathrm{ml}$ of basic salt solution (BSS), Cortland medium, at $\mathrm{pH} \mathrm{7,6}$ and $20 \pm 1^{\circ} \mathrm{C}$, with no special gas atmosphere. Each vial contained ovarian fragments with $230 \pm 30$ oocytes that had completed vitellogenesis. None of the oocytes had undergone maturation (germinal vesicle breakdown : GVD), although 50-60 \% showed GV in the peripheral zone close to the micropyle. As indicated by the position of $\mathrm{GV}$, the rest were oocytes in younger maturational stages. Ovarian fragments from all females were divided into two groups :

- group I : oocytes incubated in medium supplemented with gonadotropin or one of the steroid hormones, but without $\mathrm{T}_{3} 19$ subgroups, 1 control without any hormone ; fig. 1) ;

- group II : oocytes incubated in medium supplemented with gonadotropin or one of the steroid hormones and with $T_{3}\left(9\right.$ subgroups, 1 with $T_{3}$ alone ; fig. 1).

The centrifuged chh was added to the medium at a dose of $100 \mu \mathrm{g} / \mathrm{ml}$. Partially purified carp gonadotropic hormone (pp c-GHT) was used at a dose of $100 \mathrm{ng} / \mathrm{ml}$ of medium. Steroids, i.e. testosterone (T), androsterone (A),

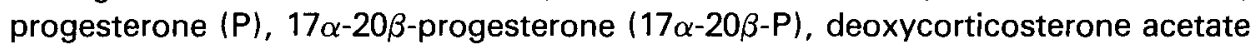
(DOCA) and cortisone acetate were used at a dose of $1 \mu \mathrm{g} / \mathrm{ml}$ and $T_{3}$ at a dose of $0.5 \mu \mathrm{g} / \mathrm{ml}$. After incubation the oocytes were cleared in turpentine oil, and the number of mature oocytes was counted under a light microscope to calculate the percentage of maturation. Hypophyses were collected into acetone from spawners in the autumn and stored as powder. Pp c-GTH (prepared by Dr. B. Breton) and $17 \alpha-20 \beta-P$ were obtained from INRA (France); the other steroid hormones were purchased from Merck Co. $T_{3}$ was purchased from Fluk AG Buchs SG. The results are presented at the percentage of mature oocytes with GVBD obtained for each treatment of the oocytes of each fish. The data obtained were checked by analysis of variance to determine if differences 

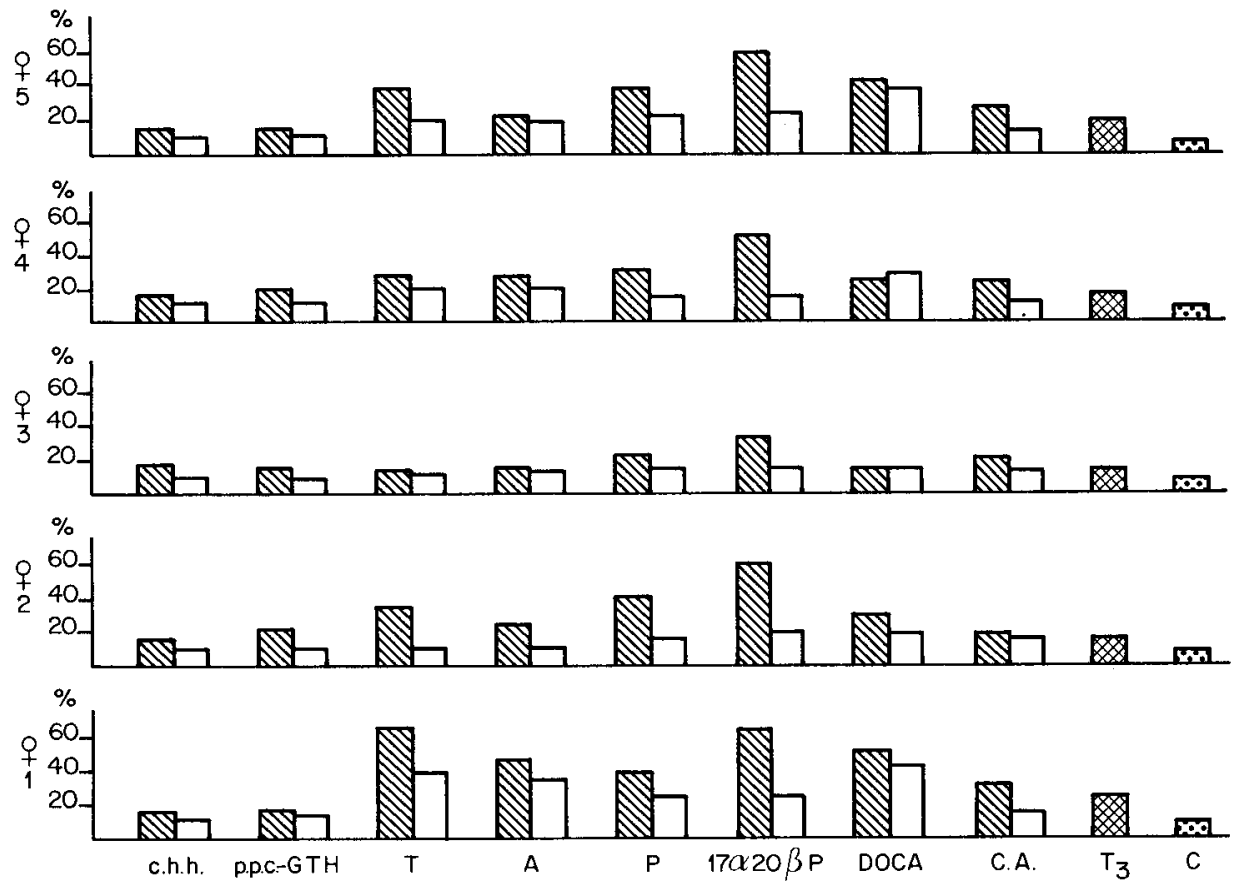

hormonest $T_{3} \square$ hormones without $T_{3} \quad$ only $T_{3}$

FIG. 1. - Percentage of mature carp oocytes obtained in media with $T_{3}$ and in media without $T_{3}$ chh : carp hypophysial homogenate ; pp c-GTH : partly purified carp gonadotropin hormone ;

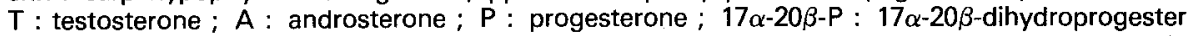
one ; DOCA : deoxycorticosterone acetate ; $C A$ : cortisone acetate $; \mathrm{T}_{3}:$ trilodothyronine ; $\mathrm{C}$ : control.

between the percentage of mature oocytes in the first and second groups after $24 \mathrm{~h}$ of incubation were statistically significant.

\section{Results and discussion.}

The percentage of mature oocytes was higher in group $\|$ (with $T_{3}$ ) than in group I (without $\mathrm{T}_{3}$ ) in 43 cases out of 45 studied (fig. 1, table 1). In one case it was the same (female no. 3, DOCA, fig. 1) and in the other it was a little lower (female no. 4, DOCA, fig. 1) ; the percentage of mature oocytes appeared to be more statistically significant $(P<0.01)$ in group II than in group I (table 2).

The addition of testosterone, androsterone, progesterone, $17 \alpha-20 \beta$-progesterone, DOCA cortisone acetate or $T_{3}$ alone to the medium caused a significant increase in the percentage of mature oocytes compared to the control (fig. 1, table 1). This agrees with results obtained by Epler $(1981 a, b, c)$ who found that the steroids and gonadotropic hormones used in our study stimulated carp oocytes to mature in vitro. The addition of $T_{3}$ alone caused about the same increase in the percentage of mature oocytes as the addition of any of the steroid 
TABLE 1

Percentage of mature carp oocytes obtained in media with $T_{3}$ and in media without $T_{3}$

\begin{tabular}{|c|c|c|c|}
\hline \multirow{2}{*}{$\begin{array}{l}\text { Subgroup } \\
\text { (hormone) }\end{array}$} & \multirow{2}{*}{$\begin{array}{c}\mathrm{N}^{\circ} \\
\text { of females }\end{array}$} & \multicolumn{2}{|c|}{ Group } \\
\hline & & I without $T_{5}$ & II with $T_{3}$ \\
\hline \multirow[t]{2}{*}{$\begin{array}{l}\text { Carp hypophysial } \\
\text { homogenate }\end{array}$} & \multirow{2}{*}{$\begin{array}{c}1 \\
2 \\
3 \\
4 \\
5 \\
\text { Mean } \\
\text { Standard } \\
\text { deviation }\end{array}$} & $\begin{array}{l}12 \\
10 \\
10 \\
11 \\
11 \\
10.8\end{array}$ & $\begin{array}{l}16 \\
16 \\
18 \\
17 \\
26 \\
18.6\end{array}$ \\
\hline & & 0.84 & 4.22 \\
\hline \multirow[t]{2}{*}{ pp c-GTH } & \multirow{2}{*}{$\begin{array}{c}1 \\
2 \\
3 \\
4 \\
5 \\
\text { Mean } \\
\text { Standard } \\
\text { deviation }\end{array}$} & $\begin{array}{l}16 \\
10 \\
10 \\
12 \\
12 \\
12\end{array}$ & $\begin{array}{l}18 \\
22 \\
16 \\
20 \\
17 \\
18.6\end{array}$ \\
\hline & & 2.45 & 2.41 \\
\hline \multirow[t]{2}{*}{ Testosterone } & \multirow{2}{*}{$\begin{array}{c}1 \\
2 \\
3 \\
4 \\
5 \\
\text { Mean } \\
\text { Standard } \\
\text { deviation }\end{array}$} & $\begin{array}{l}40 \\
10 \\
12 \\
20 \\
21 \\
20.6\end{array}$ & $\begin{array}{l}68 \\
36 \\
14 \\
38 \\
40 \\
39.2\end{array}$ \\
\hline & & 11.87 & 19.21 \\
\hline \multirow[t]{2}{*}{ Androsterone } & \multirow{2}{*}{$\begin{array}{c}1 \\
2 \\
3 \\
4 \\
5 \\
\text { Mean } \\
\text { Standard } \\
\text { deviation }\end{array}$} & $\begin{array}{l}36 \\
10 \\
14 \\
20 \\
20 \\
21\end{array}$ & $\begin{array}{l}48 \\
26 \\
16 \\
27 \\
23 \\
28\end{array}$ \\
\hline & & 9.90 & 11.98 \\
\hline \multirow[t]{2}{*}{ Progesterone } & \multirow{2}{*}{$\begin{array}{c}1 \\
2 \\
3 \\
4 \\
5 \\
\text { Mean } \\
\text { Standard } \\
\text { deviation }\end{array}$} & $\begin{array}{l}26 \\
16 \\
14 \\
15 \\
22 \\
18.6\end{array}$ & $\begin{array}{l}48 \\
26 \\
16 \\
27 \\
23 \\
28\end{array}$ \\
\hline & & 5.18 & 11.98 \\
\hline \multirow[t]{2}{*}{$17 \beta-20 \beta-\mathrm{P}$} & \multirow{2}{*}{$\begin{array}{c}1 \\
2 \\
3 \\
4 \\
5 \\
\text { Mean } \\
\text { Standard } \\
\text { deviation }\end{array}$} & $\begin{array}{l}26 \\
20 \\
16 \\
16 \\
25 \\
20.6\end{array}$ & $\begin{array}{l}66 \\
62 \\
44 \\
52 \\
63 \\
57.6\end{array}$ \\
\hline & & 4.77 & 9.15 \\
\hline
\end{tabular}




\begin{tabular}{cccc}
\hline & 1 & 44 & 54 \\
& 2 & 20 & 32 \\
& 3 & 16 & 16 \\
& 4 & 30 & 27 \\
& 5 & 40 & 46 \\
& Mean & 30 & 25 \\
& Standard & 12.16 & 15.13 \\
deviation & 1 & 16 & 32 \\
Cortisone acetate & 2 & 18 & 20 \\
& 3 & 14 & 22 \\
& 4 & 12 & 20 \\
& 5 & 15 & 30 \\
& Mean & 15 & 26 \\
& Standard & 2.24 & 5.10 \\
\hline & deviation & 1 & 26 \\
& 2 & 10 & 18 \\
& 3 & 10 & 16 \\
& 4 & 10 & 22 \\
& 5 & 10 & 20 \\
& Mean & 10 & 4.00 \\
\hline
\end{tabular}

TABLE 2

Analysis of variance.

\begin{tabular}{|c|c|c|c|c|}
\hline & Sum of squares & Of & Mean square & F ratio \\
\hline $\begin{array}{l}\text { Between-group } \ldots \ldots \ldots \ldots \\
\text { Within-group } \ldots \ldots \ldots \ldots \ldots \\
\quad \text { Total } \ldots \ldots \ldots \ldots \ldots\end{array}$ & $\begin{array}{r}3559.5111 \\
13754.8889 \\
17314.4000\end{array}$ & $\begin{array}{l}1 \\
88 \\
89\end{array}$ & $\begin{array}{r}3559.5111 \\
156.3056\end{array}$ & $22.7728^{* *}$ \\
\hline
\end{tabular}

** Statistically significant $(p<0.01)$.

hormones. However, when $T_{3}$ was added to the medium with any of the steroid hormones used, or with chh and pp c-GTH, it caused an increase in the percentage of mature oocytes compared to the same steroid or pituitary hormone treatment without $T_{3}$.

The results obtained in this study demonstrate that $T_{3}$ affects the last stages of carp oocyte maturation (GVBD). These results also confirm those obtained by Hurlburt (1977), but that author worked with $\mathrm{T}_{4}$ in goldfish in vivo. Hurlburt found that thyroid hormones act synergistically with gonadotropin on ovarian development in goldfish and that $T_{4}$ increases ovarian sensitivity to gonadotropic stimulation.

$\mathrm{T}_{3}$ may play an indirect role by stimulating the metabolic processes in oocytes, thus making the oocytes more sensitive to the effect of steroids or 
gonadotropic hormones. The direct effect of $T_{3}$ on carp oocyte maturation cannot be excluded either. Our results also suggest that $T_{3}$ and $17 \beta-20 \alpha-P$ may work together since the combination of these gave the greatest response. If these results are confirmed by in vivo experiments, thet could be of importance in fishery practice.

\section{Conclusion.}

$T_{3}$ has an indirect or direct effect on the maturation of carp oocytes.

Reçu en octobre 1982. Accepté en juillet 1983.

Acknowledgements. - This work was supported by a grant from IRS-Poland (no. PR-4). The authors wish to thank Dr. R. Peter for critically reviewing the manuscript.

Résumé. Effet de la triiodothyronine, de la gonadotropine et d'hormones stéroïdiennes sur la maturation in vitro d'ovocytes de carpe (Cyprinus carpio L.).

Les effets de la triiodothyronine, de la gonadotropine et d'hormones stérö̈diennes sur la maturation de l'ovocyte de carpe in vitro ont été examinés. Les fragments ovariens provenaient de 5 femelles en fin de vitellogenèse. Dans les sous-groupes où les hormones gonadotropes et stéroïdiennes sont associées à la triiodothyronine les pourcentages d'ovocytes matures sont significativement plus élevés $(P<0,01)$ que lorsque ces hormones sont utilisées seules.

\section{References}

BARANNIKOVA I. A., 1978. Hormonal regulation of reproduction of acipensiridae. Tr. VINRO 130, part 2, 6-15 (In Russian with English abstract).

DETTLAFF F. A., DAVYDOVA S. J., 1979. Differential sensitivity of cells of follicular epithelium and oocytes in the stellate sturgeon to unfavorable conditions and correlating influence of triiodothyronine. Gen. comp. Endocrinol., 39, 236-243.

EPLER P., 1981a. Effect of steroid and gonadotropic hormones on the maturation of carp ovaries. Part II. Effect of fish and mammalian gonadotropins on the maturation of carp oocytes in vitro. Pol. Arch. Hydrobiol., 28, 95-102.

EPLER P., 1981b. Effect of steroid and gonadotropic hormones on the maturation of carp ovaries. Part III. Effect of steroid hormones on the carp oocyte maturation in vitro. Pol. Arch. Hydrobiol., 28, 103-110.

EPLER P., 1981c. Effect of steroid and gonadotropic hormones on the maturation of carp ovaries. Part IV. A combined action of steroid hormones and HCG or fish hypophysial homogenate on carp oocyte maturation in vitro. Pol. Arch. Hydrobiol., 28, 111-118.

FONTAINE M., 1976. Hormones and the control of reproduction in aquaculture. J. Fish. Res. Board Can., 33, 922-939.

HUNT D. W. C., EOLES J. G., 1976. The influence of testosterone propionate on thyroid function of immature rainbow trout (Salmo gairdneri). Gen. comp. Endocrinol., 37, 115-121. 
HURLBURT M. E., 1977. Role of the thyroid gland in ovarian maturation of the goldfish, Carassius auratus L. Can. J. Zool., 55, 1906-1913.

LAM T. J., PANDEY S., NAGAHAMA Y., HOAR W. S., 1978. Endocrine control of oogenesis, ovulation and oviposition in goldfish, 55-64. In GIELARD P. J., BOER H. H., Comparative endocrinology. Elsevier/Nord-Holland biomed. Press, Amsterdam.

OLIVEREAU M., OLIVEREAU J., 1979. Effect of estradiol-17 $\beta$ on the cytology of the liver, gonads and pituitary and plasma electrolytes in the female freshwater eel. Cell Tiss. Res., 199, 431-454.

SAGE M., BROMAGE W. R., 1970. The activity of the pituitary cells of the teleost Poecilla during the gestation cycle and the control of the gonadotropic cells. Gen. comp. Endocrinol., 14, $127-136$.

SAGE M., BERIN H. A., 1971. Cytophysiology of the teloost pituitary. Int. Rev. Cytol., 31, 339-376. 